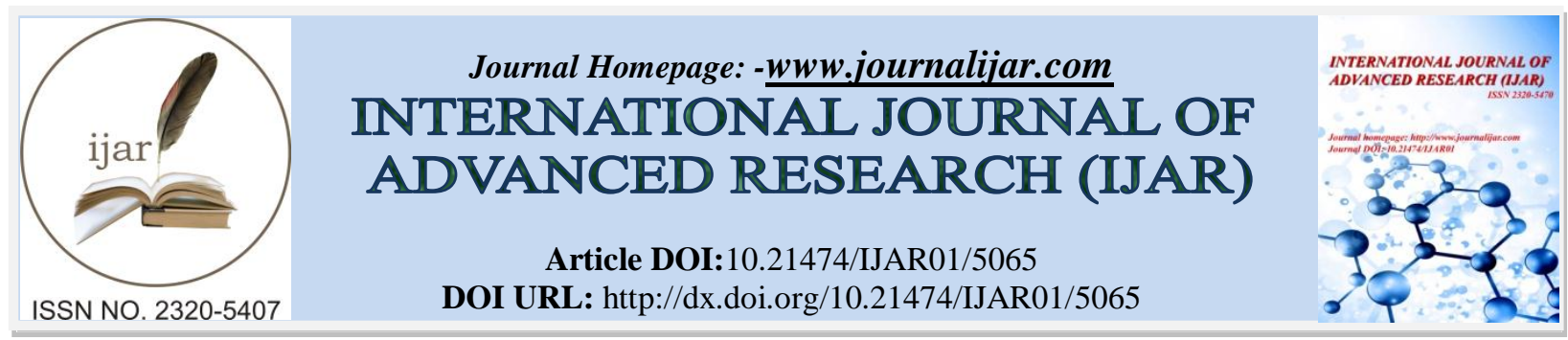

RESEARCH ARTICLE

\title{
THE USE OF THE ABSOLUTE POWERTRANSFER OF LAND RIGHTS BASED ON THE VALUE OF JUSTICE.
}

\author{
Dr. Farid,S.H. M.H. M.Kn. Prof. Dr. H. Gunarto, S.H. S.E. Akt. M.Hum. and Dr.WahyuWidodo,S.H. \\ M.Hum. \\ Student of Unissula Semarang Legal Doctoral Program.
}

\section{Manuscript Info}

Manuscript History

Received: 04 June 2017

Final Accepted: 06 July 2017

Published: August 2017

Key words:-

Instructions Minister of the Interior

No. 14, 1982, Power of Absolute

Assignment of Land.

\section{Abstract}

Absolute Power of Attorney as prohibited by Instruction Minister of the Interior No. 14 The Year 1982 is a form of the treaty law, namely the power of attorney agreement. Definition of agreements pursuant to Article 1313 of Law Book OF Private Law is an act by which one or more persons bind himself to one or more other people. Thus the covenant is a conformity of the will between two or more parties to achieve a certain thing. An agreement is considered valid, if it has qualified the validity of the agreement as set forth in Article 1320 of Law Book of the Civil Code, namely:

1. existence the agreement; 2.proficiency; 3 . a certain thing; 4 . For the law full cause.

In contract law recognized the principle such as freedom of contract, which means that everyone is free to make or not make an agreement that they want regardless of its form, extent not inconsistent with law, morality and public order, according to Article 1337 Code of Civil law specify. The principle of Article 1338 is reflected in the Code of Civil. From this understanding, it can be concluded that a person in making a free agreement of a certain form or formality good agreement granting absolute power and other agreements. The Absolute Power of Attorney is a misrepresentation of the power of attorney agreement. Definition of power granting agreement pursuant to Article 1792 Code of Civil Law is an agreement by which a give power to another person who received it, for in his name conducting an affair.

From the results of research that has been done in juridical / normative, it can be concluded that the Absolute Power of Attorney as referred to in Instruction Minister of the Interior No. 14/1982 such, is not contrary to the principle - the principle of contract law as set forth in the book too - III of the Code of Civil Law. In other words, the existence of Instruction Minister of the Interior No. 14/1982 is unconstitutional Higher Law which is contrary to the Code of Civil Law and Law of the Republic of Indonesia no. 4 The Year 1996 on Rightful Land Rights Land Related Objects. In accordance with Article 7 (1) of Law Number 12 The Year 2011, the de jure existence Instruction Minister of the Interior No. 14/1982 is null and void. It is therefore advisable for officials in the Land office as well as the Notary / PPP AT not to refuse to serve the manufacture and or use of the Absolute Power of Attorney. 


\section{Introduction:-}

The Republic of Indonesia is a state based on law, where the legal system adheres to principle lex Superior Derograt Legi Priori - which means a Laws - the lower the invitation should not be contrary to the Laws - the higher law. If it happens then the lower legislation is null and void. From this principle it can be concluded that the law/ regulation laws that exist in the first Indonesia must not contradict each other between Regulation - invitations lower by Regulation reserved - a higher law. This means that each of Laws - an invitation to be interrelated, thus reflecting their harmonization into an inter laws

Groundnorm From all sources of law applicable in Indonesia is Pancasila and the Constitution of the Republic of Indonesia Year 1945 is the highest source of law. As the implementation of the principles of lex Superior Derograt Legi Priori, the Indonesian government through the Council of Representatives as making authority Law has adopted the Law of the Republic of Indonesia No. 12 The Year 2011 on the Establishment of Laws. The law is a legal system adopted by Indonesia today. The philosophy of Law No. 12 The Year 2011 on the Establishment of Legislation is based on the idea that the State of Indonesia is a state of law. As a legal state, then all aspects of life in the field of society, nationality, and state including government should be based on the law in accordance with the national legal system.

Law No, 12 The Year 2011 mentioned above is a manifestation of the implementation of the mandate of Article 22 A Constitution of the Republic of Indonesia Year 1945, which stated that further provisions on procedures for the establishment of laws - laws governed by laws.

In this era of community life, almost every transaction is binding the parties will be poured in a deed/writing, which can be a lease agreement, purchase agreement, authorization agreement, and much more. All of it is intended to prove that if there is any occurrence of a breach of a promise (WANs pre Stasi) from one of the parties, then the party who feels aggrieved may demand a return for the accomplishment of achievment, can also demand the cancellation of the agreement or can also claim compensation.

In this study, the authors will limit and only discuss the agreement granting absolute power, as referred to in the first Instructions Minister of the Interior No. 14 The Year 1982, dated March 6, The Year 1982 On Prohibition of Manufacture and Use Authorization Absolute is an Assignment of Land. The Code of Civil law not recognize the term as well as understanding the Absolute Power of Attorney, however, where yes is not prohibited. Even in Article 15 paragraph (2) of the Constitution of the Republic of Indonesia No. 4 of 1996 on Mortgage of Land and Their Objects Relating to Land ${ }^{1}$, allowed. Similarly, in the opinion of J. Satrio, That/ The law itself stipulates that the power to impose Mutual Right is an Absolute Power. Thus, an authorization cannot be revoked was valid when the agreement became the basis of the power of attorney has a pedestal (title) valid law.

Absolute Power of terms and understanding are known only in Instruction Minister of the Interior No. 14 The Year 1982. Definition of Absolute Power according to Instructions Minister of the Interior No. 14 The Year 1982 , is the power that it contains the elements cannot be withdrawn by the authorizer, and which is essentially a transfer of land that is the power which authorizes the proxy to control and use the land and undertake all legal actions which by law can only be done by The right holder.

The Absolute Power or often called the Absolute Power of Attorney is a form of the Covenant, the Power of Attorney Agreement. Regulation on the law of treaties the authorization itself, set in the sixteenth chapter - Book III - About Engagement - the Code of Civil law. In the Code Article 1792 Code of Civil Law stated that the authorization is an agreement by which a giving power to another person, who received it, for in his name conducting an affair ${ }^{4}$. In the hierarchy of the rules per sub - regulations in force in the Republic of Indonesia, Existence The Code of Civil Law And the Law of the Republic of Indonesia no. 4 In 1996, according to the provisions of Article 7 paragraph (1) of Law No. 12 the Year 2011, a much higher position than Instructions Ministry of the Interior No. 14 The Year 1982. Therefore, by basing on The principle of lex Superior Derograt Legi Priori, the presence Instructions Ministry of the Interior No. 14 The Year 1982 is null and void, at - least to be canceled. 


\section{Discussion:-}

Instructions ministry of the Interior No. 14 The Year 1982, On the Prohibition of Making and Use Authorization Absolute as the Assignment of Land, issued on March 6, 1982. Similarly, the Government Regulation of the Republic of Indonesia no. 24 of 1997 (PP No. 24 Th. 1997) Land Registration neighbor, in Article 39 paragraph (1) letter $\mathrm{d}^{5}$; stated that: Land Deed Official (PPAT) refused to make the deed, if one party or both parties to act on the basis of an absolute power of attorney, which essentially contains the legal act of transfer of rights. In principle, the article mandates to the Land Deed Authority (PPAT) to reject the making the absolute power of attorney. From both these regulations, in principle, prohibit the manufacture and uses a letter of absolute power (absolute power)for transfer of rights over land. Definition of absolute power by Instruction Minister of the Interior is the power that it contains the elements cannot be withdrawn by the endorser; and absolute power which is essentially a transfer of land rights is absolute power which authorizes the proxy to control and use the land and undertake all legal actions that legally can be done by the rights holder.

Absolute power is a part of the law of promise and is one form of power-giving agreement. The legal arrangement of the agreement is set out in The Civil Code - the third book on the Alliance. Definition of authorization under article 1792. The Code - the Civil Code is an agreement by which a giving power to another person, who received it, for in his name conducting an affair ${ }^{6}$. In contract law recognized the principle of freedom of contract (contracts Rij Heid) which means that everyone is free to make or not make an agreement that they of any kind, as long as it is not contrary to the Act - Law, morality and public order, according to the Code Article 1337 Civil of determine ${ }^{7}$.

This principle is an essential principle in the law of covenant. The principle of Article 1338 is reflected in the Code of Civil .

From such understanding can be concluded that a person in making the free agreement of both form and certain formalities agreement granting absolute power and other agreements.

Indeed the regulation of the legal agreement itself actually regulated in the Act - the Civil Code, according to the

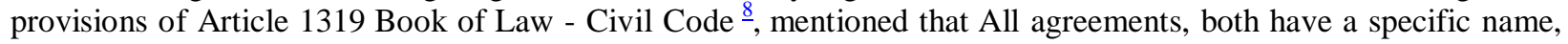
or not well-known by a specific name, subject to the rules - general regulations, contained in this chapter and the last chapter. (This chapter and the last chapter, it means that there is the third book - About Engagement, first chapter, and second chapter Book of Law - Civil Code). The purpose of the article is, that if you want to create a provision relating to the law of treaties, should refer to the provisions contained in the book too - III Civil Code, meaning not to contradict each other.

Absolute power is not recognized in the draft - the Civil Code, however, its existence is not forbidden, even in practice, absolute power has been recognized by the Supreme Court of the Republic of Indonesia ( MARI) in several decisions, among others, MARI Decision No. 3604. K / P.d.t. / 1985 , dated 17 November 1987 states that: About letter of absolute power, there is no regulation in The Code of Civil Law, setting absolute power in addition to the R.v recognized also by the Jurisprudence as BEST ENDING EN GEBRUIK KELIJK DING, besides that there is also a power of attorney inalienable and not canceled because of the death of the authorizer, in Indonesia has a BEST ENDING, so it does not conflict with the Code of Civil Law.

Similarly, the Law of the Republic of Indonesia no. 4 of 1996 on Mortgage of Land and Their Objects Relating to Land (UU HT No. 4 The Year 1996) in Article 15 (2) in principle allowed absolute power. The full sound of the article is the power to impose Mortgage cannot be withdrawn or cannot be ended by any cause except because good has been executed or having expired $\frac{10}{}$.

In addition contrary to the Code of Civil Law and Legal of the Republic of Indonesia No. 4 The Year 1996 on the right of dependents on the land and the objects related to the land; The two rules above also contradicts Article 28 of the Constitution of the Republic of Indonesia Year 1945 (UUDRI 1945). In Article 28 of the Constitution of the Republic of Indonesia Year 1945, Determined that there should be any kind of discrimination, including discrimination laws / by laws. The legal discrimination is obvious when in referring to the wording of Article 15 paragraph (2) UU HT No. 4 The year 1996. That power to impose Mortgage as referred to in Article 15 paragraph (2) is equal to the absolute authority as referred to in Instructions Ministry of the Interior No. 14 The Year 1982 and PPRI no. 24 The year 1997 - Article 39 paragraph (1) letter d, I e, the power cannot be withdrawn by any cause; The power is used for removal/transfer of land rights. Like wise in opinions expressed J. Satrio, that: The law itself establishes that the authority to make Encumbrance is the Power of the Absolute. Thus it is clear that 
Instructions Ministry of the Interior No. 14 of 1982 and PPRI no. 24 of 1997 on Land Registration is contrary to UUDRI 1945. By, therefore, it is appropriate principles adopted in the system of law in Indonesia, namely principle lex Superior Derograt Legi Priori, the presence of both the regulations that Instructions Ministry of the Interior No. 14 of 1982 and Article 39 paragraph 2 letter d - PPRI No. 24 The Year 1997 is null and void.

Similarly to the Law of the Republic of Indonesia No. 12 The Year 2011 on the Establishment of laws - laws (by Law No. 12 The Year 2011), both the above regulations that Instructions Ministry of the Interior No. 14 The Year 1982 and Article 39 paragraph 2 letter d - PPRI No. 24 The year 1997 is contradictory. According to Article 7 paragraph (1) UURI No. 12 of 2011, the two regulations are Instructions Ministry of the Interior No. 14 of 1982 and Article 39 paragraph 2 letter d - PPRI No. 24 The Year 1997, hierarchy position far below The Constitution of the Republic of Indonesia 1945 ( UUD RI ) 1945; Code of Civil law; UUHT RI No. 4, 1996. Thus, according to the principles adopted in the legal system in Indonesia, namely principle lex Superior Derograt Legi Priori, the presence of both the regulations that Instructions Ministry of the Interior No. 14 The Year 1982 and Article 39 paragraph 2 letter d - PPRI No. 24 The Year 1997 is null and void.

Based on normative juridical research performed by the author, it can be concluded that the existence Instructions Ministry of the Interior No. 14 The year 1982 and Article 39 paragraph (1) letter d- PP No. 24 The Year 1997 was contrary to Laws - laws that are contrary to the higher one. The Constitution of the Republic of Indonesia 1945; 2. Law of the Republic of Indonesia No. 12 The year 2011 on the Establishment of laws - laws; 3. Code of Civil law; 4. Law of the Republic of Indonesia No. 4 The year 1996 on Mortgage of Land and Their Objects Objects Relating to Land.

The Author found where Instructions Ministry of the Interior No. 14 The Year 1982 and Article 39 paragraph (1) letter d - PPRI No. 24 The Year 1997; Instead of making the order and legal certainty in the registration of land, but instead creating the absence of legal certainty, which in the end justice as the ideals of the law will not be realized. Thus the two regulations are according to the author does not have the value of expediency. Such a situation is proved that in Indonesia, he said the rule of law, but in fact, there are any known harmony and lack harmonization in laws, even contradictory. Constitution legislation in a country is an integral part or sub-systems of a system of law in the country, so as to achieve the purpose of the law, then there must be an effort alignment/harmonisation of legislation in various forms and levels must be interlinked, aligned, and do not overlap so as to establish a legal system that is solid, effective move dynamically once comprehensively in a unified system law in the country, in other words there should be harmonisation Regulation of legislation.

From the results of research that has been done, the authors argue that the existence of Instructions Ministry of the Interior No. 14 of 1982 and Article 39 paragraph (2) letter d - PPRI No. 24 years 1997 is contrary to the legal system adopted by Indonesia, which is contrary to the Law of the Republic of Indonesia Number 12 the Year 2011 on the Establishment of laws. So in accordance with the principle / Indonesian legal system, namely the Principle of lex Superior Derograt Legi Priori, both these regulations become null and void, and or advisable for reconsideration.

\section{Conclude:-}

Instruction Ministry of the Interior of the Republic of Indonesia on March 6, The Year 1982 No. 14 The Year 1982 on the Prohibition of Use Power of the Absolute as the displacement of Land and Article 39 paragraph (1) letter d PPRI No. 24 The Year 1997 is contrary to legislation higher. In this case contrary to the Civil Code, and also contrary to Law no. 4 The Year 1996 on the Deposit Rights. Though both the legislation hierarchically, a higher position than the regulation. So in accordance with the principle of the rule of law in Indonesia, namely the principle of lex Superior Derograt Legi Priori, the presence of both these regulations Retained Earnings de jure void as a matter of law and not legally binding.

Instruction Ministry of the Interior of the Republic of Indonesia No. 14 of 1982 and Article 39 paragraph (1) letter d - PPRI No. 24 Th. 1997, contrary to article 28 Constitution of the Republic of Indonesia Year 1945, which set should not be any kind of discrimination, including discrimination laws / by laws. Therefore, the presence of both these regulations, be null and void.

In terms of authority. Instructions Ministry of the Interior No. 14 The year 1982 and Article 39 paragraph (1) letter d - PPRI No. 24 The year 1997, Established not by virtue of their authority. For the matter of arranging the contract law (power of attorney agreement), it is actually set out in the Civil Code. And to amend or reduce the provisions 
contained in the Civil Code is the right and authority of the House of Representatives on the executive's proposal on behalf of the President. In this case, the Minister of Home Affairs is no more than auxiliary to the President, so that if the will to propose/regulate the matter of the law of the treaty, it should be through the President to be further discussed in the House of Representatives. That because of Instructions Ministry of the Interior of the Republic of Indonesia No. 14 In 1982 it was formed by not based on authority, then in accordance with Article 8, paragraph (2) of Law Number 12 The Year 2011 on the Establishment of legislation, both these rules do not have binding legal force.

\section{Bibliography:-}

\section{Book / Literature:-}

1. Ali Boediarto, 2000 abstract compilation of laws, Supreme Court decisions about the law of the land, Jakarta, IKAHI.

2. R. Subekti \& Tjitrosudibio, 1992, Code of Civil law, Pradnya Paramita, Jakarta, p. 282.

3. Satrio, J; Legal Guarantee, Material Warranty Rights, Book Deposit Rights 2 - Bandung, PT. Aditya Citra Bhakti, p 187, 2004.

\section{Legislation:-}

1. Constitution - Constitution of the Republic of Indonesia 1945.

2. Law of the Republic of Indonesia no. 12 The year 2011 About the Establishment of Laws and Regulations.

3. Law of the Republic of Indonesia no. 4 The year 1996 on Rightful Land Rights - Land Related Objects. Government Regulation No. 24 The Year 1997 on Land Registration

4. Minister of the Interior Instruction No. 14 The year 1982 on the Prohibition of Use Power of Absolute Assignment for Land. 